\title{
Shakespeare in the Post-1989 Hungarian Puppet Scene
}

\author{
Gabriella Reuss
}

\begin{abstract}
Although according to popular belief puppet theatre is a children's amusement while Shakespeare traditionally belongs to live theatre, in Hungary the two acting traditions seem to come together in the 2000s, bringing positive changes in both spheres. Theatre practitioners elsewhere in the Central European region have already experimented with 'the third genre' (JURKOWSKI 2014: 33), namely, a new way of theatrical expression featuring actors and puppet elements on stage. Indeed, talented theatre directors could often find no work in any other domain. In Hungary, where puppet theatres were obliged to cater to no one else but a very young audience and were thus for the general adult spectatorship often overlooked, the time has come only in the post-1989 decades to explore this new and highly metaphorical theatrical language. The era has produced changes in puppetry training and puppetry as educational medium. Within this environment, relatively few stagings of Shakespeare were produced, although these included remarkable productions by Krofta and Balogh in 2006, and by Somogyi and Szikszai in 2018.
\end{abstract}

\section{Key words}

Shakespeare, The Tempest, A Midsummer Night's Dream, Macbeth, puppet theatre/puppetry, method acting, Rémusz Szikszai, Josef Krofta, Géza Balogh, Dezső Garas, Tamás Somogyi, Jan Císař, DRAK, Budapest Puppet Theatre, Harlekin Puppet Theatre 


\section{"'Puppet?" Why so?' (MND 3.2.299)}

\section{Theory and practice in the mid-1980s}

Encountering Shakespeare is, always and for all companies, extraordinary, but at least a special and uncommon event. [...] Here I do not mean to announce that the puppet theatre claimed the giant of the live theatre for itself, as this was not the first attempt to use the text as performance material for something other than the live actor's body. [...] The root of the question lies not in the meeting of Shakespeare and the puppet theatre. Much rather, the question is what novelty this meeting brings. ${ }^{1}$ (CÍSA ̌̌ 1990: 33)

Such a rendezvous poses several challenges; firstly, what extra quality puppets can bring, and secondly, how the Shakespearean text is to be positioned in a medium in which the verbal component is integrated in 'design, movement and speech systems of equal importance' (BARAITSER 1999: 1). Puppetry is not an art suitable for long and unwieldy monologues; so then how does it respond to all of Shakespeare's 'words, words, words'? In a review of A Midsummer Night's Dream as interpreted by the DRAK Puppet Theatre (Hradec Králové, Czechoslovakia, 1984), critic Jan Císař opined that the novelty of the production was indeed paradigm changing, and that at the core of DRAK's success was its treatment of the Shakespearean text, namely, the way the literary and linguistic textures were entirely subjugated to the scenic structure and expression (CÍSA ̌́ 1990: 34).

Although Jan Císař wrote the above appraisal thirty-five years ago, the challenge of Shakespeare's words as performed by marionettes and hand puppets remains the same in contemporary Hungary. It is still relatively infrequent that puppet theatres choose to perform Shakespeare; yet it is not this fact in itself that requires attention, but the particular ways Shakespearean drama can be illuminated by the potentials of this uncommon interpretive medium. Has anything changed in an environment in which most of the Hungarian participants at the $7^{\text {th }}$ Pécs International Puppet Festival (1985) were justly condemned in Olga Panovová's report for being 'mechanic,' 'illustrative', and thus obviously incapable of offering any adult performances? (PANOVOVÁ 1990: 79)

Even if the first Hungarian puppet Shakespeare had been staged as early as 1964, no other Shakespeares followed. The State Puppet Theatre's close to eighty premieres were all but one addressing toddlers and small children; it was a rare occasion for the State Puppet Theatre, the only professional puppet theatre of the time, to target a mature audience. It was 1979's A Midsummer Night's Dream (dir. Kató Szőnyi, composer György Ránki) which marked the beginning of the three decades while Dezső Szilágyi, the production's dramaturg, was artistic director at the State Puppet Theatre. During the years of Szilágyi’s management (1962-1992) the State Puppet Theatre experimented with a few music-based productions that were either originally written for ballet (e.g., Stravinsky's Petrushka, Bartók's The Wooden Prince and The Miraculous Mandarin), or were singspiels, musical pieces (e.g., János vitéz [John the Knight] and A császár új ruhája

$1 \quad$ All translations are my own unless otherwise stated. 
[The Emperor's New Clothes]) (KROÓ 1978: 50). Productions only used homogeneous tools/puppet types; the puppeteers never came out from behind the screens, and the issue of the puppet-animator relationship was not explored. The impact of Szilágyi's rejection of mixed live actor-and-puppet productions, which in 1967 Jurkowski named as the 'third genre' which 'demand[s] critical evaluation' (JURKOWSKI 2014: 33), was indeed sweeping and lasting; and these stagings ultimately seem to have deserved Olga Panovová's condemnation. All the more, at the time future puppeteers were exclusively trained at the State Puppet Theatre's one-year course. It was this institution, thanks to Socialist centralisation, that provided all the puppet performances in Hungary, ${ }^{2}$ be them inside the capital or outside of it, thus there was no way around what the State Puppet Theatre represented.

Císařs 1985 contentions, which influenced the Hungarian puppet scene from their publication in the country in 1990, seem useful to serve as a compass for the present study. We ought to keep in mind that 'theatre traditions are inspired, created, developed and recognised through cultural encounters - from the initial enchantment with the exotic and the shock at the "Other"' (BILLING and DRÁBEK 2015: 6). The paper will explore the intersection of two sets, Shakespearean production as well as puppetry in the three post-Socialist decades of Hungary. For points of reference, we will refer to the framework of Central European puppetry and the reception of Shakespeare. The study will point out and describe a few important Shakespearean productions using citations from theatre historians, theorists, directors, and critics about particular productions and tendencies. Nevertheless, by no means is the attempt here to re/draft a history of Hungarian puppetry exhaustively listing all significant personalities, ${ }^{3}$ and thus we will look back on the era before the change of political regime only when necessary.

\section{'Into something rich and strange' (Tempest 1.2.474)}

\section{The appearance of the live actor and the response to DRAK's A Midsummer Night's Dream}

One of the reasons why this study begins with Císař's 1985 statement is that it is perhaps more topical than ever with regards to today's Hungarian puppet scene, and it locates a formative criterion of good (puppet) theatre: puppetry should not be used to merely illustrate some higher purpose, e.g., Shakespeare's untouchable text. Instead, the Shakespearean text, its poetry and savagery, its rhythm and philosophy, should all be conveyed through the visually and musically autonomous puppet medium, using 'the poetic metaphor of the puppet' (JURKOWSKI 2014: 33) - to which I will return later.

2 The Appendix, a separate folded leaf bearing the title 'Az Állami Bábszínház múvészei, 1977' [The Artists of the State Puppet Theatre in 1977] effectively supports this claim with the portraits of the company members. At the time of the edition there were 64 puppet animators employed by the State Puppet Theatre (SZILÁGYI 1978).

3 See Géza Balogh's (2010) erudite monograph A bábjáték Magyarországon. A Mesebarlangtól a Budapest Bábszinházig [Puppet Art in Hungary. From Mesebarlang to the Budapest Puppet Theatre]. 
During the decades of Hungarian Socialism, actors were required to create a sense of complete realism on the live theatre stage, whereas puppeteers in turn were expected to create the sense of complete illusion. Here it is necessary to mention that theatre aesthetics in Central European Socialisms were determined by the way reality was meant to be perceived along with the way Stanislavski's methods were to be exploited in a particular country. For instance, the Hungarian version of Socialist Realism demanded performers to reach back to Stanislavski's Method, to explore the motivations of their stage characters; however, they were expected to find these motivations in terms of class struggle. The authorities' insistence on photo realism created a wide gap between literal and figurative performance, between stage realism in live theatre and stylised/ illusionist staging in puppet theatre. Consequently, puppeteers were never visible; they were never set physically in contrast to their puppets; they were never in meta-dialogue with them about what theatre was. Even so, Leonora Spet, the dramaturg who worked with the influential Russian puppeteer Obraztsov, gave a talk in Warsaw at the UNIMA Congress on the live actor's presence within the puppet theatre as early as in 1962 (ČESAL 1983: 26), and theoretical writings appeared such as Miroslav Česal's illustrated monograph Živý herec na loutkovém divadle [The Live Actor in the Puppet Theatre] in 1983. Yet despite these initiatory discussions regarding the juxtaposition of the live actor with the puppet on stage, in Socialist Hungary this phenomenon hardly appeared in practice. In contrast to the situation in Czechoslovakia, where according to Miroslav Česal the mixed, live actor-and-puppet production was not exceptional by 1983 (ČESAL 1983: 27), in Hungary the phenomenon affected neither the aesthetic nor the power structure, and the dichotomy of 'live actor/realism for adults' vs. 'puppet/illusion for children' held sway for several more decades. Playing invisibly behind a screen not only limited the number of types of puppet a production could use, but it also seriously curtailed the interpretive potential of the production.

This has completely changed in the post-1989 era: by now it is quite trendy for puppeteers to perform visibly. The issues triggered by the more or less emphatic presence of the animator and the puppet in the same show comprise the bulk of contemporary critical discourse.

That the use of both puppets and live actors should stem from an organic, structural, and conceptual necessity rather than anything else is a criterion that was (again) explicitly formulated as a requirement by critic and theatre historian István Nánay in his 2018 review of the $14^{\text {th }}$ Meeting of Hungarian Puppet Theatres at Kecskemét. A decades-long puppet enthusiast, Nánay's criticism repeatedly made it clear that without establishing a consistent and systematic relationship between the animator and the puppet, no production would ever successfully present Shakespeare. Considering the performer's and the puppet's acting, Nánay demanded clear indications regarding the focal points, and emphasised that 'it is of key importance to define this [relationship] precisely from both aesthetic and interpretive aspects' (NÁNAY 2018: 78). To illustrate the state of affairs in Hungary, i.e., the necessity of definitions and the necessity of the autonomy of the puppet medium (independent of the text), allow me to refer to Nánay again from a year later in an interview intended for the lay reader: first he pointed out the 
difference between puppet theatre and children's theatre (apparently an absolute necessity to emphasise), then he concluded that a puppet theatre production can qualify as good theatre only when it is defined by the features typical of the puppet medium, for instance, abstract musical and visual structures (TURBULY and NÁNAY 2019). The play text was thus not the priority. In the same year Andrea Stuber, another vastly experienced critic, asked 'Why puppets, what for? What cannot be expressed without puppets, solely through the body of the actor?' (STUBER 2020). Stuber indicated how imperative it is to acknowledge that the process of this substantial change in Hungarian puppet art, its coming of age in terms of rejecting sheer illustration and illusion, has been taking place in the present right before our eyes.

The famous staging of A Midsummer Night's Dream at DRAK directed by Josef Krofta which Císař wrote about (see above) and which Hungarian puppeteers made a pilgrimage to see in the 1980s pointed out the direction which Hungarians were to follow. The stages of this path can be very well signposted by the relatively challenging and also relatively few Hungarian puppet Shakespeares.

Even from the beginning, the reactions to DRAK's 1984 A Midsummer Night's Dream were not unambiguous; they ranged from enchantment to shock. Hungarian director and puppet theatre historian Géza Balogh (2015) remembers both the wild applause at the Charleville (France) theatre festival as well as the vociferous debate after the performance. In the atmosphere of a smoky pub rang out a cacophony of French and Hungarian phrases, some demanding purity of puppetry from Krofta's puppet and live actor performance, while some, even former performers of the first famous Hungarian puppet Shakespeare (A Midsummer Night's Dream, 1964), were profoundly moved, amazed and inspired; nevertheless, there were also some who yelled in indignation that Krofta had in fact 'emasculated Shakespeare' (BALOGH 2015: 17).

Four years after the inspiring Dream by DRAK, the State Puppet Theatre under the management of Szilágyi eventually experimented with a live actor on the puppet stage for the first time and mounted a Tempest with the visible presence of the great thespian Dezső Garas (1934-2011) as Prospero and the rest of the cast as rod puppets moved by invisible (and practically unknown) animators. As Dezső Szilágyi was the dramaturg of the production directed by Garas, this was above all a tribute to the mature actor with the magical, velvety voice and also to the beautified puppet world of an enchanted island in the aging Szilágyi's realm. 'There was some elevated symmetry in his [Szilágyi's] project' Géza Balogh pointed out 'to end with the Tempest his professional career which he started in 1964 with A Midsummer Night's Dream' (BALOGH 2018b). Although the two productions were twenty-four years apart, as Balogh (2018b) noted, they were 'quite similar to one another', 'equally beautiful', in the sense that they 'both capitalised on miracles and illusions', and quite interestingly, on the fact that apart from these occasions the State Puppet Theatre never played Shakespeare.

Szilágyi, who adapted the Shakespearean text for the puppet stage, did not seem to take note of the fact that in the 1980s the puppet theatres of the world treated Shakespeare and other classics in a very different manner than they did twenty years earlier' (BALOGH 2018b). Four years after the eye-opening production of DRAK's Dream in 
1984, the way the company produced The Tempest at the State Puppet Theatre in 1988 was, as Balogh noted, 'a mere anachronism' (BALOGH 2018b). It was not only Géza Balogh, one of the first two Hungarians who earned their puppet director diploma from Prague's DAMU in 1964, who condemned Szilágyi and Garas's take. According to Andrea Székely, a puppet animator at Szilágyi’s State Puppet Theatre, the 1984 Dream had been seen by many in the Socialist bloc, e.g., at the International Puppet Festival in Dresden, even if DRAK did not tour Hungary. As the Czechoslovak production was widely held as an important milestone in the renewal of puppet theatre dramaturgy, it is quite unlikely that Szilágyi was unaware of its achievements.

In sum, Szilágyi's and Garas's text-centred, highly poetic tale ${ }^{4}$ closed an era and opened a new one. This production, one that displayed the essence of the musical puppet theatre that became Szilágyi's brand abroad (VARGA 2016), was not hailed excessively, yet met a warm reception, and eventually the show attracted adult audiences to the State Puppet Theatre. Although the treatment of the text, i.e., the particular puppet dramaturgy that Císař held so important was not yet addressed, the ramifications of the co-presence of the puppet and its animator eventually began to appear, and the practitioners of Hungarian puppetry were inspired to discover 'something rich and strange' (Tempest 1.2.474).

\section{'What fools these mortals be?' (MND 3.2.112.)}

\section{Preparing for Shakespeare}

When in 1990 Márta Tömöry edited Ember és báb [Man and Puppet] (TÖMÖRY 1990: 7-9), the first anthology for students of puppetry, she hoped that just as the horizons of travelling opened up after the fall of the barbed wire that used to surround the country, the horizons of new puppet tendencies would open up wide as well. Although today it may seem a thin and unassuming volume in rather cheap print with poor quality black-and-white pictures, Tömöry's volume, subtitled 'Bábszínházak, műhelyek, kísérletek' [Puppet Theatres, Workshops, Experiments], represents an immediate response to events with regard to the puppet art in the Central European region, and it still proves invaluable for puppeteers and researchers. Since the 1960s, fifteen booklets have been published for puppet artists, all of them engaging solely with technical issues. Tömöry featured translations of excerpts by a selection of contemporary authors like Císaŕ, Česal, and Schohn. ${ }^{5}$ Further, in addition to the theoretical writings that had been so sorely missing from the palette of Hungarian puppet education, she also included personal reports (SZÉKELY 1990: 97-101) about festivals and foreign performances with puppets. Firstly, because in the Socialist reality travelling abroad had been severely hindered and limited, and secondly, because the education of puppet animators consisted

4 We can find a model or at least a kindred predecessor in Jiř́ Trnka's narrated, charming, entirely puppeted film adaptation of A Midsummer Night's Dream (1959).

5 Interestingly, Jurkowski is not present in the volume. 
of a mere one-year training practice, these news/descriptions and analyses/messages from the outside world proved more than welcome.

Viewed retrospectively, Tömöry's anthology was an unequivocal statement that Hungarian puppetry needed to seek new ways to target new layers of grown audiences, and in doing so, Czech puppet art was a clear inspiration to follow. A proper tertiary level education was needed if the Hungarian scene sought to take up the challenge of staging adult performances and, eventually, to wrestle with the dramaturgy necessary to play Shakespeare.

Tertiary education in study programmes for puppet animators and directors started in 1995 and 2008 respectively at the University of Theatre and Film Arts (SzFE). The impact of these two courses is more than perceptible today. The young puppet artists, specialising in puppet making, dramaturgy, directing or animation, have been progressively conquering the Hungarian stages, and not only in puppet theatres. It will likely be these artists (along with their professors) who experiment with new forms of theatrical and abstract expression, and thus bring change to the dominant realist style. Due to the influence of the directors who either established or taught/teach in the two majors of SzFE's puppet education programmes, puppet actors are not exclusively employed by puppet or children's theatres. Inversely, puppets have appeared in the performances of established theatres, in Caryl Churchill's The Skriker (2013) at the Katona József Theatre, The Wizard of Oz (2015) at Vígszínház [Comedy Theatre], Ernő Szép's Emberszag (2015) at the Szkéné Theatre, McDonagh’s The Pillowman (2017) at the Radnóti Theatre, and Macbeth (2018) in Tatabánya/Szkéné, Budapest. To illustrate the new generation's characteristically flexible attitude towards theatre, their deviation from realist acting, their insistence on figurative performance and metaphorical way of thinking, allow me to quote the very young puppet director Attila Fige: 'in case I am invited to a live theatre to direct a play, of course I will not say no. However, I will take a puppet with me' (PAPP 2016).

While writing these lines about the finally established state-of-the-art puppet education at $\mathrm{SzFE}$ and its impact on the theatre profession, the expertise and even the very existence of the two puppet majors and their international Erasmus Mundus MA diploma have become endangered. Thinly veiled as a 'change in the financing model,' the government has taken full control over the university by authorising a board of exclusively government-appointed trustees to act in place of the university's senate and rector in all matters of human resources, finance, and education. Two trustees out of the five have nothing to do whatsoever with theatre theory and practice, and none were aware of the nature, the content, nor even the name of the available training programmes $^{6}$ at the university they were to govern from 1 September 2020 . Via the 'change

6 In an article in Magyar Nemzet Online (6 August 2020), Tamás Lajos, one of the appointed trustees, urged SzFE to establish a film and video screenwriter training programme, which he did not even realise already exists. In fact, scriptwriters and dramaturgs have been trained at SzFE for 19 years, since 2001. Lajos was also unaware of the fact that SzFE students of scriptwriting and dramaturgy have been nominated three times for the Student Oscars, and that they have also won once. See https://eduline.hu/felnottkepzes/magyar_ eselyes_a_diakOscaron_Q3LBNI or https://eduline.hu/felsooktatas/20200811_szfe_forgatokonyviro_kepzes. The films entered into competitions can be found at: www.docnomads.eu, www.viewfinder-ma.eu. 
in the financing model', director Attila Vidnyánszky came to absolute power as the appointed Head of Trustees. Vidnyánszky is openly hostile towards alternative ways of theatrical expression (e.g., puppetry); thus a severe reduction in the variety of training to a mere two specialities (actor and director) might be expected. ${ }^{7}$ Such a perspective seems all the more damaging, as it was only quite recently that what was once a utopian dream that Balogh and Krofta nursed, extended international co-operation between the Prague Academy of Performing Arts (DAMU) and SzFE (BALOGH 2018a), has come to life as a joint English language Erasmus Mundus MA diploma in 'PuppeTry' in cooperation with the Academies of Performing Arts in Bratislava (Slovakia), Prague (Czech Republic) and Białystok (Poland). ${ }^{8}$

\section{'The play's the thing' (Hamlet 2.2.604)}

\section{Krofta and Balogh's 2006 Dream at the Budapest Puppet Theatre}

Establishing a new field of training always requires high goals as well as inspiring examples: one of these inspirations was A Midsummer Night's Dream at the Budapest Puppet Theatre (former State Puppet Theatre) in 2006. Even if the DRAK's 1984 A Midsummer Night's Dream left the 1988 Budapest Tempest almost intact, it left a lasting influence on those who became the creators and the audiences of the next puppet Shakespeare. In 2006 Géza Balogh initiated a collaboration with Miloslav Klíma and Josef Krofta. With Klíma, Balogh acted as the co-dramaturg of the production, creating the script for the performance using the translations by János Arany, István Eörsi, and Ádám Nádasdy. With a text that reflected Krofta's idea to highlight the erotic dimension of the play, they created a most successful, 'third genre'/live actor and puppet performance, providing memorable intellectual input for the creators (SZEMERE 2006) as well as for the audience.

One incongruity that makes puppet theatres in general so reluctant to turn to, or even to avoid, Shakespeare is immanent in the nature of the art of puppetry: it is the unsuitability of the puppet stage for a dramaturgy that is inherently text-centred. György Kroó, the music composer of the State Puppet Theatre, noticed this in the late seventies in his contribution to the volume Szilágyi edited on the achievements of the State Puppet Theatre, A mai magyar bábszínház [Contemporary Hungarian Puppet Theatre] (KROÓ 1978: 53). The composer clearly explicated that it is always the action,

7 To make matters worse, Csaba Galántai (2020) wrote the article 'A magyar bábkatedra lezüllesztése' [Depraving the Hungarian Puppet Education] in Magyar Nemzet and Mandiner on 16 September 2020 that was equally charged politically and personally (plus factually slanting). In the article, he accused a small circle of amateur, unprofessional, liberal individuals of depraving puppet education at SzFE as judged by Christian nationalist professionals like himself. In response, a petition was signed by all Hungarian puppet theatre practitioners along with an official open letter written by the Hungarian Puppetry Guild (Art Limes, 19 September 2020) rejecting in unison Galántai's statements as deliberately divisive.

8 More on the Erasmus Mundus English language MA: http://szfe.hu/hogyan-keszulj-afelvetelire/\#1540462746917-d4b36c73-4182. 
the conflict, the fight that is visually and musically engaging on the puppet stage. In contrast, Kroó described a dramatic structure which he called an 'aria-dramaturgy'. Dominated by long monologues/arias with action coming only rarely, this structure can never be successful on the puppet stage (KROÓ 1978: 53).

The demand for a new dramaturgy suited to puppets has only relatively recently been acknowledged. For instance, when introducing a collection of puppet theatre plays in 1999 Marion Baraitser advised that "events or "visuals" [should be] written into the piece' (BARAITSER 1999: 4). When in the 2000s The World Encyclopaedia of Puppetry devoted a page to dramaturgy, it formulated that the puppet text must rely on 'the onomatopoeias, the exclamations, the short lines, the rhymed texts' (POLETTI et al. 2009/2012), etc. The Encyclopaedia also adds that it is not the source text but 'the manner that each type of puppet has of expressing the word determines the text and the diction' (POLETTI et al. 2009/2012). Perhaps Kroó's recognition that a puppet theatre play text is quite different from, or occasionally even opposed to, the heavily verbal Shakespearean text, contributed to Szilágyi's and the State Puppet Theatre's relative avoidance of producing Shakespeare.

As a consequence, it must be appreciated any time a puppet company feels equal to responding to the challenge that a Shakespearean text poses. These rare occasions can be considered as the zenith of a company's intellectual and artistic power. Such an influential milestone was Balogh's and Krofta's 2006 A Midsummer Night's Dream, and such a mature summary was Szikszai's 2018 Tempest. In this paper the former will receive more attention, as the latter was widely acknowledged as a breakthrough and was much more appreciated in Hungarian papers and abroad (see e.g., REUSS 2020).

Five years before the 2006 Budapest A Midsummer Night's Dream, a formative cultural encounter for Hungarians took place, the $12^{\text {th }}$ International Puppet Theatre Festival for Adults in 2001. Here Shakespeare was the most popular of all authors; moreover, the common feature of all the significant Shakespearean productions was an ironic approach that enabled puppeteers to include nonsense or absurd elements in the productions independent of the play's original genre. Actually, today's successful, often grotesque Hungarian live actor Shakespeares may owe much to the 2001 puppet festival. Balogh has stated that since then the ironic and irreverent approach to Shakespeare of puppet theatres has contaminated and effectively conquered the established Hungarian live actor theatres (see PIKLI's article in this collection).

At the Pécs Festival Hungarians became acquainted with an amazing paraphrase of Romeo and Juliet by Krofta/DRAK ${ }^{9}$, and as a consequence of this new encounter Balogh managed to invite Josef Krofta to the Budapest Puppet Theatre. As Krofta's entire oeuvre is so centred around the relationship between man and puppet as a way of expressing the subjugation of the individual to higher, manipulative forces, it was not surprising that the Czech chose a Shakespearean play. In an interview with Katalin Szemere, Krofta explained that 'it is not the puppet itself but the electric circuit between the actor and the [performing] object' that interested him (SZEMERE 2006).

9 The adaptation of Shakespeare's Romeo and Juliet was entitled Mor na ty vaše rody! [A Plague on Both Your Houses!], produced in 2001 in co-operation with a Japanese partner. 
Consequently, Krofta insisted on adapting his Shakespearean ideas to the current actors at the Budapest Puppet Theatre, and eventually decided to do the Dream for a fourth time. ${ }^{10}$ At Wroclaw in 2003 he had imagined the Dream as 'a narcotic vision' taking place amongst hippies at a Woodstock-type festival (TOMASZEWSKA 2018), and accordingly he requested Zbigniew Kornecki to add a musical score of well-known rock numbers. Three years later, as if demonstrating Shakespeare's versatility, the Budapest version capitalised on yet another aspect of the play and thus arrived at a completely different realisation.

It is indeed telling that the Budapest production ${ }^{11}$ starts in an environment that conveys the image of a Renaissance giardino, with a white marble fountain, an ice-covered pond, and pale statues of half-naked musicians and nymphs covered with brownish dead leaves on a freezing autumn afternoon. Soon after the mechanicals come on stage to sweep away the rotting leaves for their rehearsal, the fragile fountain statuette comes alive: the figure of the peeing little boy (resembling the Manneken Pis of Brussels). This turns out to be a hermaphrodite Puck, who in an instant, uses what seemed to be his willy, as his ocarina, to call the other leaf-covered statues, his fellow fairies, into play. The metaphor of the opening scene perfectly fits the state of puppetry in Hungary: Krofta-Puck's playful inspiration was able to wake up the Hungarian players, and their play breathed life into puppet art in which physically and metaphorically just anything can happen.

Krofta emphasised the liberating power of swaying playfulness that also incorporates allusions to well-known (non-puppet) productions while activating the spectator's imagination. For instance, Oberon's improbably long and hairy phallus serves a multitude of purposes, including a walking stick, a microphone, the strings of the bass, a whip, or a sexy feather boa framing Titania's décolletage. As one object morphs into another in an instant, the characters transform into different personages before our eyes.

In this nonsensical dream-universe the two mortal couples chasing one another become controllable one-meter wooden puppets under Puck's spell. The wooden 'humans' are animated by white-clothed fairies, in fact, by the same actors who impersonated them in their life-size human forms. Losing all their human essence except their desires, the puppet couples effectively embody Shakespeare's idea of the (enviable or pitiable?) spell-bound lover. With Jaroslav Milfajt's design, Krofta winks at Michael Hoffman's 1999 film in which the quartet of the lovers are wondering through the forest pushing their yellow and red bicycles: Krofta's 2006 Hungarian lovers wear these two bright colours literally on their sleeves and struggle to fix their tandem bike from time to time (see Fig. 1). Eventually, under the magical cloak of this midsummer night, where fireflies light the lovers' ways towards their respective partners, all mistakes are corrected. A cloak is spread across the stage by the mechanicals to play the role of the

10 Krofta's renderings of Shakespeare's A Midsummer Night's Dream came in 1984 (Hradec Králové, Czechoslovakia), 1998 (Friderikstat, Norway), 2003 (Wrocław, Poland), and 2006 (Budapest, Hungary) (MALÍKOVÁ 2015).

11 Here I thank Borbála Bacsó, artistic secretary of the Budapest Puppet Theatre, for her generosity in sharing with me the recording of the 2006 production. 


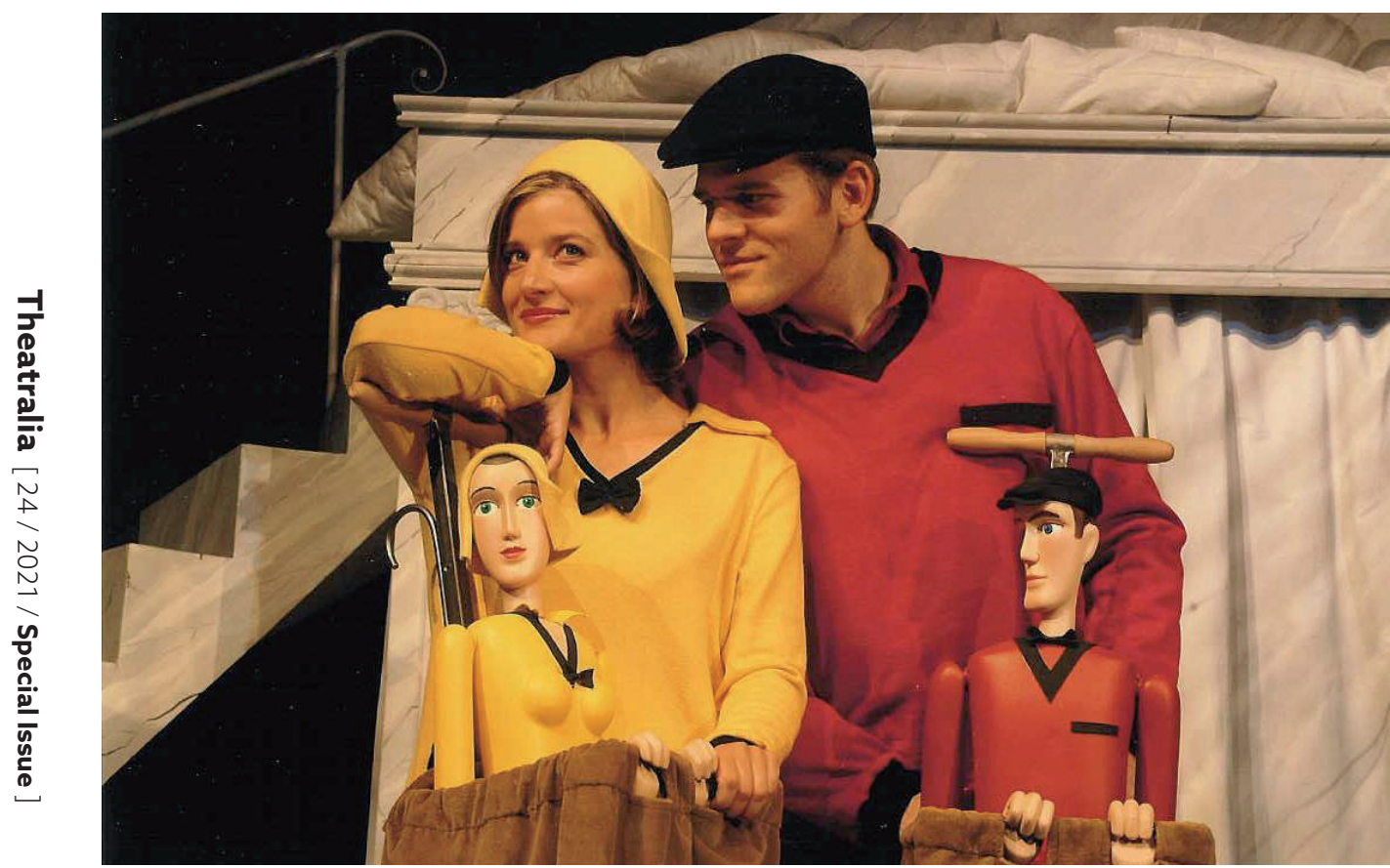

Fig. 1: Hermia (Judit Kovács) and Lysander (Csaba Teszárek) in A Midsummer Night's Dream directed by Josef Krofta at the Budapest Puppet Theatre, 2006. Puppet design: Jaroslav Milfajt. Photo: Károly Matz.

Wall: this cloak that had seemed to be a light, mysteriously transparent veil, now in daylight suddenly appears to be a huge grimy rag that awkwardly separates the two lovers in the most tragically and at once the most parodistically tearful rendering of the tale of Pyramus and Thisbe.

As for the play text, Balogh has described how the Czech director worked along the same principles as he had done in 1984 with DRAK, in Norway, and in Poland (BALOGH 2018a: 29). Characteristically, the text of the production was surprisingly thin, comprising twenty scenes and featuring only three mechanicals, yet (although a purist Shakespeare scholar might not admit) nothing seems to be sorely missing. To illustrate how the production used the metaphorical language the 'third genre' offered, I now turn to the focal point/enigma in Shakespeare's A Midsummer Night's Dream, the affair of Titania and Bottom. Some of the characters' lines are substituted for by a juicily ambiguous choreographed dance, with the deliberate result of this stylised and allusive display leaving questions and uncertainties as to the exact nature of the pair's lovemaking. Thus it seems just as unclear for the spectator as it is for Titania and Nick Bottom whether what happened in this meeting of the material with the ethereal actually happened in a dream or in the realm of the 'real'.

What Krofta and Balogh managed to achieve with their 2006 production in the long run was to spark a creative impetus towards further mixed, live-actor and 
puppet productions in which what activates the spectators' mind originates from a commingling of both Shakespeare and the relationship between the live actor and the puppet.

\section{'O excellent motion! O exceeding puppet' (TGV 2.1.94)}

\section{Szikszai's 2018 Tempest at the Budapest Puppet Theatre}

The 'electric circuit' between the players, puppets, and animators, certainly inspired Rémusz Szikszai's staging of Shakespeare's The Tempest in 2018. Szikszai (b. 1969) is a director who has grown profoundly interested in experimenting with non-realistic acting. He often produces his own play texts and is enormously enthusiastic about incubating and teaching the curriculum at SzFE's puppet majors. Following his personal interest, he has studied Indonesian rod as well as shadow and wayang puppets elsewhere in Southeast Asia (LAKNER 2017; SZIKSZAI 2019). Eventually, when Szikszai was chosen by artistic director János Meczner to mount the 2018 season's adult puppet production, he chose The Tempest for the Budapest Puppet Theatre.

Szikszai has always been engaged in representing power structures, the nature of hunger for power as well as subjugation, all of which he combines with his 'symbiosis of various puppet techniques' (BÓTA 2017). In the 2015 staging of Emberszag [The Smell of Humans] by Ernő Szép, Szikszai used almost life-size bunraku puppets to represent the helplessness and objectification of the people marked with a yellow star during the Nazi occupation of Budapest. In his 2018 Macbeth he used several performing objects, among them paper mâché puppets as Macduff's children killed onstage, chilling the audience by the bloodcurdling sound of the smashing of the paper heads (see ALMÁSI in this collection).

In his Tempest, a mature culmination of his experiments so far, ${ }^{12}$ his actors perform with a variety of puppets, the vivid symbiosis of these techniques never allowing the production design to become didactic. On one end of the scale some of the flesh-andblood actors look almost identical to their puppet (Stephano, Trinculo), while on the other there are some (Alonso, Sebastian, Antonio) whose body and real nature is covered by a life-like (plaster cast) mask (see Fig. 2) and prosthesis. The two always agreeing and rather indistinguishable courtiers Adrian and Francisco are impersonated by a single actor in one common body with two heads. Some characters, such as Miranda and Ferdinand as bunraku puppets, attempt to become independent of Prospero's influence. When they manage to slip away from the sorcerer, they appear without their puppet selves (REUSS 2020).

The commedia dell'arte scenes that Stephano and Trinculo (see Fig. 3) were given in the production evoke in both look and execution the best traditions of amusement from the strolling puppeteers' striped booth, be it the Hungarian Vitéz László or the

12 A video trailer of the production can be found at https://budapestbabszinhaz.hu/en/ babszinhazeloadasok/the-tempest/. 


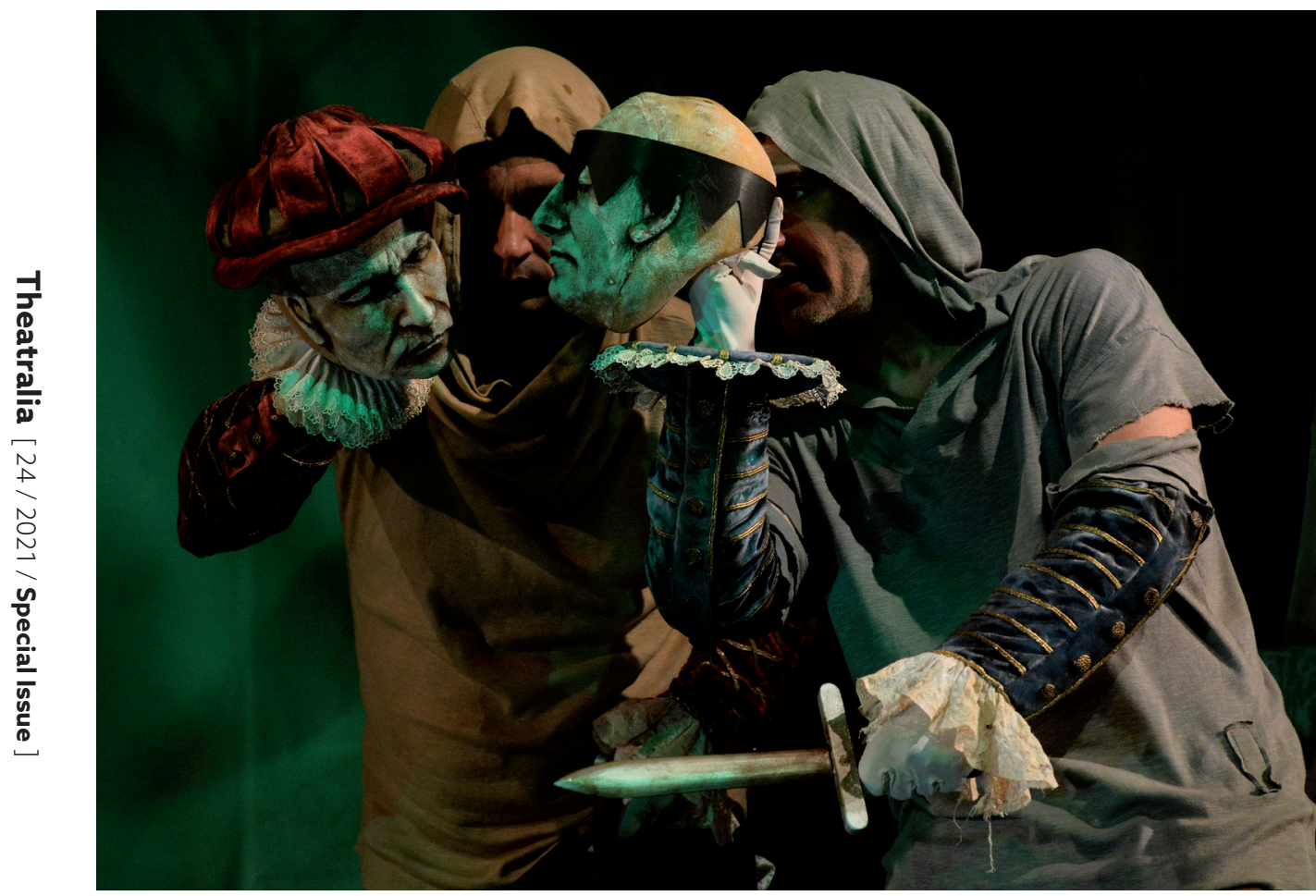

Fig. 2: Sebastian (István Kemény) and Antonio (Norbert Ács) in The Tempest directed by Rémusz Szikszai at the Budapest Puppet Theatre.

Puppet design: Károly Hoffer, costume design: Julcsi Kiss. Photo: Vera Éder.

English Punch. The production's puppet designer Károly Hoffer has Stephano appear as a huge dark green bottle whose chubby body reminds us of rural Hungarian vessels. The Trinculo character is not only the ever loud-mouthed (Punch-like) jester, but embodies both the archetype of the sad bajazzo as well as the Shakespearean wise fool. In sum, Szikszai and Hoffer meaningfully integrated various, even popular acting traditions in their Shakespeare. Szikszai's rendering fits into the ironic, grotesque, playful but by no means gently entertaining series of contemporary Hungarian Shakespeares (with or without puppets).

\section{'Enter several strange shapes' (Tempest 3.3.24)}

\section{Enter the young generation}

By the 2010s the young and the zealous, growing from the seeds sown by Balogh, Krofta, Meczner, Szikszai, and others were trying their hand at Shakespeare outside the capital and the Budapest Puppet Theatre. Since 1990, the once amateur countryside puppet companies have started to operate professionally, either as divisions of 


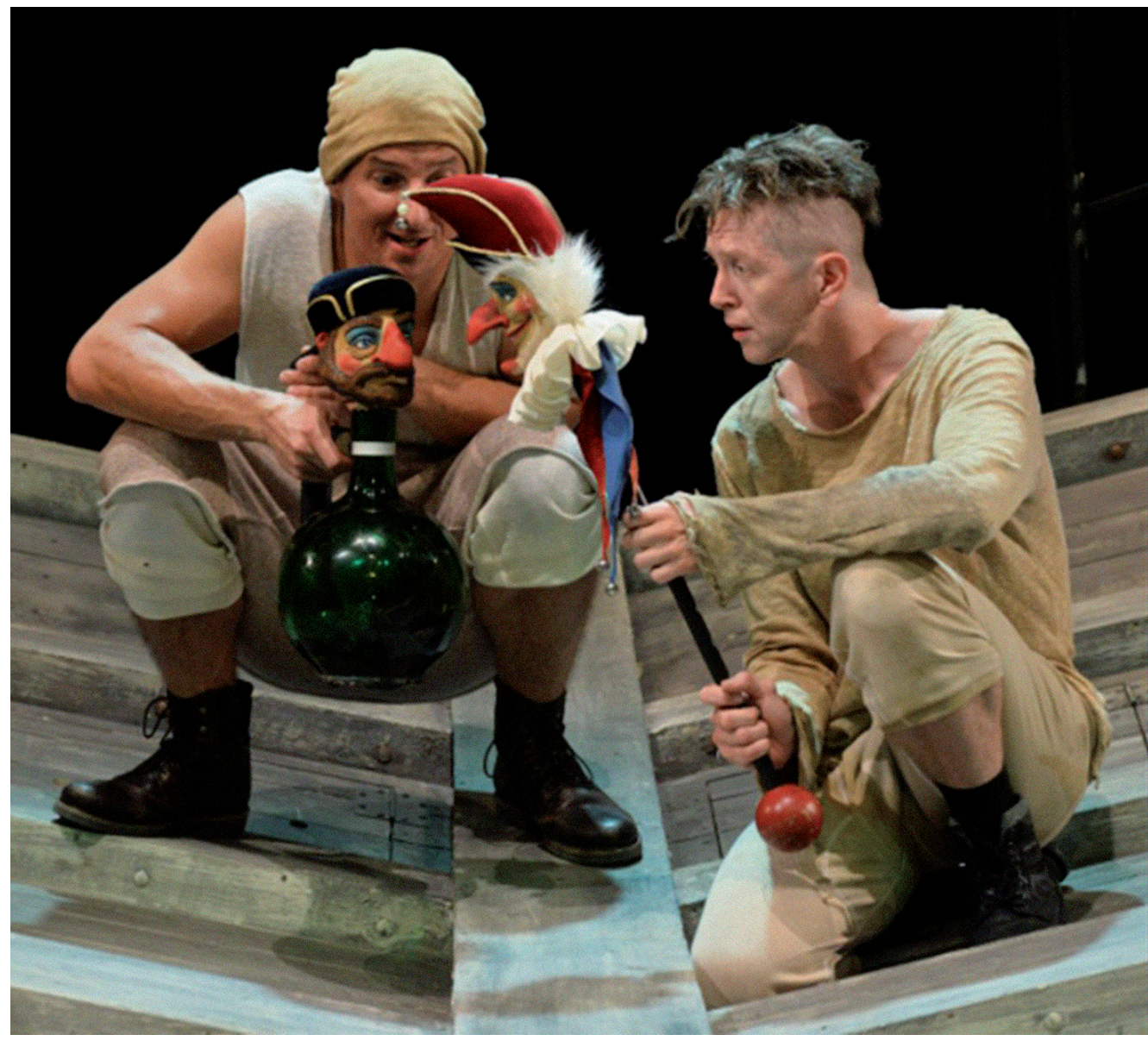

Fig. 3: Stephano (Gergő Pethö) and Trinculo (Zsolt Tatai) in The Tempest directed by Rémusz Szikszai at the Budapest Puppet Theatre.

Puppet design: Károly Hoffer, costume design: Julcsi Kiss. Photo: Vera Éder.

theatres located in regional centres or independently. As can be seen in the example of one of the oldest groups, the seventy-year-old Napsugár [Sunshine] Puppet Theatre of Békéscsaba (JÁSZAY 2019), ${ }^{13}$ the change of regime and cultural climate did not automatically solve these companies' housing problems: they have often lacked offices as well as rehearsal and performing spaces. Some have been forced to relocate frequently under humiliating terms, ${ }^{14}$ or were pressed to cater to an audience of only children in dishearteningly long runs. Despite the sea of troubles, some of the dozen professional puppet companies like the Griff Puppet Theatre of Zalaegerszeg have built up an adult audience as well; a number of groups have introduced young audiences to

13 Jászay's 2019 book is the first scholarly history of any puppet theatre established outside the capital.

14 Napsugár is lucky to operate now in Ibsen House, Békéscsaba's new cultural centre built and financed not by the Hungarian state but by the Norwegian Fund (JÁSZAY 2019). 
theatre through Shakespeare, and some have achieved several artistic and commercial successes with young adult Shakespeare productions.

The Shakespeares at the Harlekin Theatre, Eger, a company of a dozen puppeteers, is a prime example of both the devotedness and the isolation of Hungarian puppeteers. ${ }^{15}$ It is largely unknown that Harlekin's artistic director Pál Lengyel launched (in parallel with Géza Balogh's efforts) the Festival of Contemporary Puppet Art in Eger for students of puppetry from the V4 countries. With scenic and visual designers Iván Koós and László Lovassy, in 1996 Lengyel staged a puppet Twelfth Night under the title '...vagy amit akartok' [...Or What You Will], staging the play again in 2000 at Győr's Vaskakas Puppet Theatre (MIGLINCZI 2015). In 2003 Lengyel staged an open-air shadow puppet A Midsummer Night's Dream. Following Lengyel's footsteps the present artistic director of Harlekin devotes special attention to the age group of 13-18 and their initiation to the theatre, hence Harlekin's regular Shakespeares: young Tamás Somogyi ${ }^{16}$ (educated at SzFE) has staged Romeo and Juliet in 2012, Hamlet in 2014, as well as A Midsummer Night's Dream in 2017, ${ }^{17}$ and his Othello is forthcoming in 2020. Somogyi also directed an improvisation-based adaptation of A Midsummer Night's Dream titled Ide-Oda [To and Fro] in a completely different manner and genre at the Griff Puppet Theatre, Zalaegerszeg.

Regarding the script of Somogyi's Harlekin 2017 A Midsummer Night's Dream, we could apply the comments of Ewa Tomaszewska about Krofta's Wroclaw production, namely, that 'the adaptation of Shakespeare's text was a far cry from devout respect for the English Bard' (TOMASZEWSKA 2018: 103). In other words, Szaida Khaled-Abdo, Somogyi's dramaturg (educated at SzFE), considered Shakespeare's text as raw material rather than a sacred cow. Somogyi's 'visual metaphors' (MIGLINCZI 2015) on which the performance text relies leave space for scenography and the non-verbal, echoing the principles of Balogh and Krofta. The set of multiple doors and windows serving as screens of varied heights by no means resembles a forest, nor our everyday reality. The lovers are personified by live actors under the surveillance of the three-eyed Puck puppet and the fairy couple, who appear with a dreamlike absurdity as giant fish-like lanterns (see Fig. 4). The production's bravery in avoiding a tried-and-true perspective shows the liberty with which Somogyi's Shakespearean script targeted a young audience. Such inventiveness and vision deserves notice and the strongest encouragement in furthering the cause of Hungarian puppetry in its process of growing up to interpret Shakespeare and to address adults.

15 Hungary's economic imbalance, i.e., its Budapest-centred economic and intellectual life, leaves its impression on cultural life as well: usually very little is known in Budapest about what is going on in provincial towns, where the number of inhabitants is too low to make any production run long or be profitable.

16 See Somogyi's homepage at https://somogyitamasblog.wordpress.com/category/eloadasok/.

17 All Harlekin productions are created by the team of scenic and puppet designer Nóra Jakob and dramaturg Szaida Khaled-Abdo. 


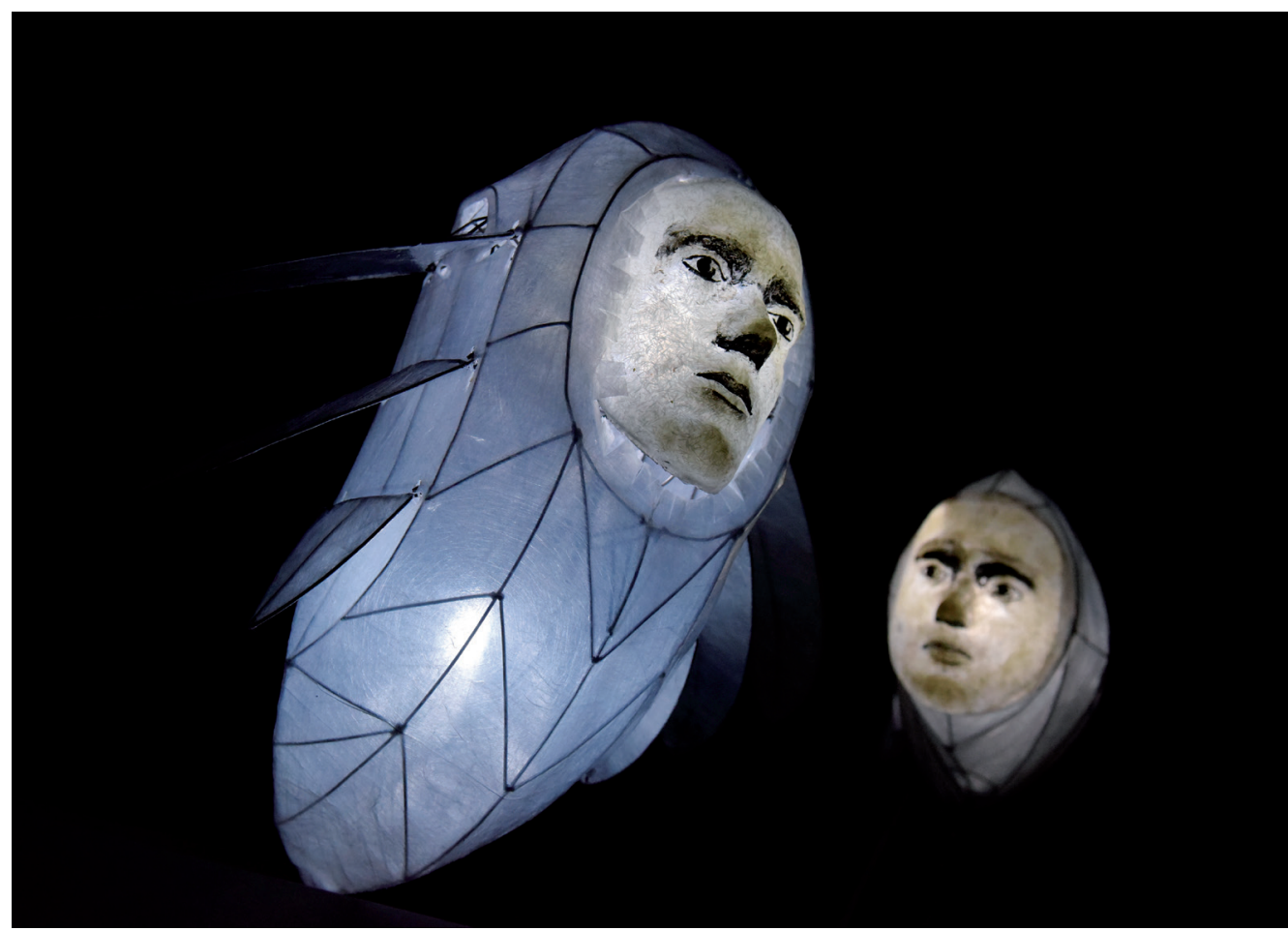

Fig. 4: Theseus and Hyppolita designed by Ottó Szabó in Tamás Somogyi's rendering of A Midsummer Night's Dream, 2017, at Harlekin Puppet Theatre, Eger. Photo: Gábor Gál, Fotoda.

\section{A curse and a blessing}

\section{Conclusion}

As we have seen, Shakespearean production offers a fairly clear cross-section and overview of the Hungarian animated theatre scene, one which has already brought Shakespeare into its creative universe. This 'living drollery' (Tempest 3.3.26) points towards the infinite variety and openness of a non-realist theatre, and, perhaps consequently, as Éva Hutvágner has pondered, not towards 'puppet shows', but full productions with puppets (HUTVÁGNER 2018) which enrich the present and future Hungarian reception of Shakespeare. This process took place four decades earlier in Socialist Czechoslovakia and Poland than it has in Hungary, a fact which only serves to demonstrate the variety of results Socialist censorship produced on the national theatre scenes of the Central European Socialist bloc. Theatre practitioners in Poland and the former Czechoslovakia, for whom 'in the difficult times of Communism [...] a puppet theatre was the only stage' (TOMASZEWSKA 2018: 96) they were allowed to work on, had no other chance but to explore and master puppetry. In contrast, at the same time 
Hungarian puppetry was infantilised to such an extent that theatre practitioners tended to avoid puppetry altogether. Eventually when Hungarian directors returned to this art after the fall of Communism they initially did so to deconstruct the local/national (and until now quite fossilised) Socialist-realist conventions. Thus it seems quite likely that Central European theatre tendencies and practitioners can only transcend the boundaries of their time, space, and medium - be it live performance, puppet theatre or the liminal spaces in between - through the production of Shakespeare.

\section{Bibliography}

ALMÁSI, Zsolt. 2018. Macbeth fojtogató és bizonytalan világa. A Macbeth Tatabányán Szikszai Rémusz rendezésében [Macbeth's Suffocating and Uncertain World. The Scottish Play in Tatabánya, Directed by Rémusz Szikszai]. Prae (2018). [accessed on 13.01.2021]. Available online at https:/ /www.prae.hu/article/10760-macbeth-fojtogato-es-bizonytalan-vilaga/ .

BALOGH, Géza. 2010. A bábjáték Magyarországon. A Mesebarlangtól a Budapest Bábszinházig [Puppet Art in Hungary. From Mesebarlang to Budapest Puppet Theatre]. Budapest: Vince Kiadó, 2010.

BALOGH, Géza. 2015. Josef Krofta a nagyvilágban (1943-2015) [Josef Krofta in the Big Wide World]. Art Limes 5 (2015): 16-29.

BALOGH, Géza. 2018a. Cseh-szlovák-magyar kapcsolatok a magyar bábművészetben. [CzechSlovak-Hungarian Relations in Hungarian Puppetry]. Art Limes 1 (2018): 20-31.

BALOGH, Géza. 2018b. Prospero mester bábszínháza [The Puppet Theatre of Master Prospero]. Criticai Lapok Online (2018). [accessed on 13.01.2021]. Available online at https://www.criticailapok.hu/2-uncategorised/39324-prospero-mester-b\%C3\%A1bsz\%C3\%ADnh\%C3\%A1za.

BARAITSER, Marion. 1999. Introduction. Contemporary Theatre Review: Theatre of Animation. Contemporary Puppet Plays in Context - 1. 9 (1999): 4: 1-12.

BILLING, Christian M. and Pavel DRÁBEK. 2015. Czech Puppet Theatre in Global Contexts: Roots, Theories and Encounters. Theatralia. Czech Puppet Theatre in Global Contexts: Roots, Theories and Encounters 18 (2015): 2: 5-31.

BÓTA, Gábor. 2017. Sikerült a félelmet úrrá tenni. Interjú Szikszai Rémusszal [Fear Has Thus Come to Rule. Interview with Rémusz Szikszai]. Szinház (31. 10. 2017). [accessed on 13.01.2021]. Available online at https://szinhaz.org/interju/2017/10/31/sikerult-felelmet-urra-tenni-interju-szikszai-remusszal/.

ČESAL, Miroslav. 1983. Živý herec na loutkovém divadle. [The Live Actor in the Puppet Theatre]. Ústav pro kulturně výchovnou činnost v Praze. Knihovnička amatérského divadla, Svaz. 6. 1983. CÍSA ̌̌, Jan. 1990. A dramaturgia korszaka [The Age of Dramaturgy]. Transl. by László R. Hollós. In Márta Tömöry (ed.). Ember és báb. Bábszinházak, múhelyek, kisérletek [Man and Puppet. Puppet Theatres, Workshops, Experiments]. Budapest: Múzsák, 1990: 33-35.

HUTVÁGNER, Éva. 2018. Animáció vagy báb? Formák és tendenciák. [Animation or Puppet? Forms and Tendencies]. Szinház (January 2018). [accessed on 13.01.2021]. Available online at http://szinhaz.net/2018/03/02/hutvagner-eva-animacio-vagy-bab/. 
JÁSZAY, Tamás. 2019. Napsugártól Napsugárig. Történetek a hetvenéves békéscsabai bábjátszásról [From Sunshine to Sunshine. Stories from the 70-year Long History of Békéscsaba Puppetry]. Békéscsaba: Békéscsabai Napsugár Bábszínház, 2019.

JURKOWSKI, Henryk. 2014. Aspects of Puppet Theatre. Ed. by Penny Francis. London: Macmillan, 2014. KROÓ, György. 1978. A látvánnyá varázsolt zene. In Dezső Szilágyi (ed). A mai magyar bábszínház [Contemporary Hungarian Puppet Theatre]. Budapest: Corvina, 1978: 50-55.

LAKNER, Zoltán. 2017. Fegyverünk az igazság. Szikszai Rémusz: A színház sem kerülheti el az öntisztulást [Armed by the Truth. Rémusz Szikszai: The Theatre Cannot Avoid Self-Purification]. 168 óra Online (20. 11. 2017). [accessed on 13.01.2021]. Available online at https://168ora. hu/kultura/egy-halott-csecsemovel-probaltam-erzekeltetni-hogy-nincs-jovo-szikszai-remusz-aszinhaz-sem-kerulheti-el-az-ontisztulast-12733.

MALÍKOVÁ, Nina. 2015. Josef Krofta. In The World Encyclopaedia of Puppetry Arts. [accessed on 13.01.2021]. Available online at https://wepa.unima.org/en/josef-krofta/.

MIGLINCZI, Éva. 2015. Harlekin Kortárs Bábművészeti Napok - első nap. [Harlekin Festival of Contemporary Puppet Art - Day One]. Art Limes (11. 05. 2015). [accessed on 13.01.2021]. Available online at http://www.artlimes.hu/cikk?id=413.

NÁNAY, István. 2018. Bábszínház, vagy színház bábokkal? Tizennegyedszer Kecskeméten [Puppet Theatre or Theatre with Puppets? Kecskemét, for the $14^{\text {th }}$ Time]. Art Limes 5 (2018): 73-83. [accessed on 13.01.2021]. Available online at https://epa.oszk.hu/03000/03095/00032/pdf/ EPA03095_art_limes_2018_5_073-083.pdf.

PANOVOVÁ, Olga. 1990. A ki nem használt lehetőség, avagy nincs téma a felnőttek számára? A VII. Pécsi Nemzetközi Bábfesztiválról [The Missed Opportunity or, are There no Subjects to Offer for Adults?]. Transl. by Pálné Szincsók. In Márta Tömöry (ed.). Ember és báb. Bábszinházak, mühelyek, kisérletek [Man and Puppet. Puppet Theatres, Workshops, Experiments]. Budapest: Múzsák, 1990: 70-72.

PAPP, Tímea. 2016. Kezdetben vala az Állami Bábszínház. [Once upon a Time There was the State Puppet Theatre]. Fidelio (5. 01. 2016). [accessed on 13.01.2021]. Available online at https://fidelio.hu/szinhaz/nevek-szamok-babosok-22846.html.

POLETTI, Michel and the Editorial Committee. 2009/2012. Dramaturgy. Transl. by Claudia Orenstein and John McCormick. In The World Encyclopaedia of Puppetry Arts. [accessed on 13.01.2021]. Available online at https://wepa.unima.org/en/dramaturgy/.

REUSS, Gabriella. 2020. Mors Bona, or Storm in a Tea Cup? Shakespeare's Tempest in a Puppet and Live-actor Production. Représentations dans le monde Anglophone 1 (2020): 105-127. [accessed on 13.01.2021]. Available online at https://representations.univ-grenoble-alpes.fr/ IMG/pdf/7-reuss-2.pdf.

SHAKESPEARE, William. 2020. A Midsummer Night's Dream. Ed. by Barbara Mowat et al. Washington: Folger Shakespeare Library. [accessed on 13.01.2021]. Available online at https:// shakespeare.folger.edu/shakespeares-works/a-midsummer-nights-dream/.

SHAKESPEARE, William. 2020. The Tempest. Ed. by Barbara Mowat et al. Washington: Folger Shakespeare Library. [accessed on 13.01.2021]. Available online at https://shakespeare.folger. edu/shakespeares-works/the-tempest/. 
SHAKESPEARE, William. 2020. The Two Gentlemen of Verona. Ed. by Barbara Mowat et al. Washington: Folger Shakespeare Library. [accessed on 13.01.2021]. Available online at https:/ / shakespeare.folger.edu/shakespeares-works/the-two-gentlemen-of-verona/.

STUBER, Andrea. 2020. Lélektanmesék [Tales of the Soul]. Színház.net (June 2020). [accessed on 13.01.2021]. Available online at http://szinhaz.net/2020/06/11/stuber-andrea-lelektanmesek/.

SZÉKELY, Andrea. 1990. A tenger az tenger, a kád az kád? A cseh DRAK Bábszínház közelről [The Ocean is Ocean, the Tub is Tub? A Close Look at the Czech DRAK Puppet Theatre]. In Márta Tömöry (ed.). Ember és báb. Bábszinházak, mühelyek, kísérletek [Man and Puppet. Puppet Theatres, Workshops, Experiments]. Budapest: Múzsák, 1990: 97-101.

SZEMERE, Katalin. 2006. Bebábozódott szerelmesek [Metamorphosis of Lovers]. Népszabadság (28. 09. 2006). [accessed on 13.01.2021]. Available online at http://nol.hu/archivum/ archiv-418903-229546.

SZIKSZAI, Rémusz. 2019. Nem keserűségből megyek el - interjú Szikszai Rémusszal. [I am Leaving but not Because of Bitterness. Interview with Rémusz Szikszai]. Interview by Annamária Jász. WeLoveBudapest (10. 04. 2019). [accessed on 13.01.2021]. Available online at https:// welovebudapest.com/cikk/2019/4/10/nem-keserusegbol-megyek-el-interju-szikszai-remusszal. SZILÁGYI, Dezső. 1978. Az Állami Bábszínház bemutatói [The Productions of the State Puppet Theatre]. In Dezső Szilágyi (ed.). A mai magyar bábszinház. Budapest: Corvina, 1978: 62-71.

TOMASZEWSKA, Ewa. 2018. A Midsummer Night's Dream in Polish Puppet Theatres in Silesia Mise-en-scène by Jan Dorman, Josef Krofta and Marián Pecko. Theatralia 21 (2018): 2: 95-111. TÖMÖRY, Márta. 1990. Preface. In Márta Tömöry (ed.). Ember és báb. Bábszinházak, múhelyek, kisérletek [Man and Puppet. Puppet Theatres, Workshops, Experiments]. Budapest: Múzsák, 1990: 7-9. TURBULY, Lilla and István NÁNAY. 2019. Pedig a báb intim műfaj [Yet the Puppet is an Intimate Genre]. Interview by Bálint Kovács. Szinház.net (28. 12. 2019). [accessed on 13.01.2021]. Available online at http://szinhaz.net/2019/12/28/pedig-a-bab-intim-mufaj/.

VARGA, Nóra. 2016. Szilágyi Dezső és az egyik első magyar bábesztétika. Az Állami Bábszínház felnőtt Kísérleti Stúdiója. [Dezső Szilágyi and One of the First Hungarian Puppetry Aesthetics. The Experimental Studio for Adults of the National Puppet Theater. Title translated by Nóra Varga]. Art Limes 54 (2016): 13/3: 5-9. [accessed on 13.01.2021]. Available online at http:// epa.oszk.hu/03000/03095/00018/pdf/EPA03095_art_limes_2016_3.pdf. 


\section{Gabriella Reuss}

Department of English Literatures and Cultures, Institute of English and American Studies,

Pázmány Péter Catholic University

Mikszáth Kálmán tér 1., 1088 Budapest, Hungary

reuss.gabriella@btk.ppke.hu

ORCID: https://orcid.org/0000-0003-4409-8137

Gabriella Reuss is a senior lecturer in English Literature at Pázmány Péter Catholic University, Hungary. Many of her publications concern the promptbook of the earliest, 1834 restoration of the tragically ending King Lear. In her first monograph, Shakespeare Londonban és PestBudán. Színházi előadások emlékezete [Shakespeare in London and Pest-Buda. Remembering Performances] (L'Harmattan, Budapest, 2017), she studied W. C. Macready's and Gábor Egressy's paradigm-changing performances of Lear as represented in their uniquely parallel 1838 playtext manuscripts. Her research interests include performance criticism and the $19^{\text {th }}-21^{\text {st }}$ century reception of Shakespeare in both live actor and puppet theatre. 